\title{
Contemporary Art Practice and Indigenous Knowledge
}

McMaster, Gerald

\section{Suggested citation:}

McMaster, Gerald (2020) Contemporary Art Practice and Indigenous Knowledge.

Zeitschrift für Anglistik und Amerikanistik, 68 (2). pp. 111-128. ISSN 0044-2305 Available at http://openresearch.ocadu.ca/id/eprint/3092/

Open Research is a publicly accessible, curated repository for the preservation and dissemination of scholarly and creative output of the OCAD University community. Material in Open Research is open access and made available via the consent of the author and/or rights holder on a non-exclusive basis.

The OCAD University Library is committed to accessibility as outlined in the Ontario Human Rights Code and the Accessibility for Ontarians with Disabilities Act (AODA) and is working to improve accessibility of the Open Research Repository collection. If you require an accessible version of a repository item contact us at repository@ocadu.ca. 


\title{
Gerald McMaster*
}

\section{Contemporary Art Practice and Indigenous Knowledge}

https://doi.org/10.1515/zaa-2020-0014

\begin{abstract}
Indigenous artists are introducing traditional knowledge practices to the contemporary art world. This article discusses the work of selected Indigenous artists and relays their contribution towards changing art discourses and understandings of Indigenous knowledge. Anishinaabe artist Norval Morrisseau led the way by introducing ancient mythos; the gifted Carl Beam enlarged his oeuvre with ancient building practices; Peter Clair connected traditional Mi'kmaq craft and colonial influence in contemporary basketry; and Edward Poitras brought to life the cultural hero Coyote. More recently, Beau Dick has surprised international art audiences with his masks; Christi Belcourt's studies of medicinal plants take on new meaning in paintings; Bonnie Devine creates stories around canoes and baskets; Adrian Stimson performs the trickster/ruse myth in the guise of a two-spirited character; and Lisa Myers's work with the communal sharing of food typifies a younger generation of artists re-engaging with traditional knowledge.
\end{abstract}

\section{Introduction}

Indigenous contemporary art, whether practised on Canada's West Coast, the Prairies, the Great Lakes, the Maritimes, or the Arctic, has always been inextricably tied to Indigenous or traditional knowledge. In virtually all regions of Canada, it is the bond that gives Indigenous contemporary artists a particular identity amongst other artists. In the not-so-distant past, many artists of Indigenous heritage eschewed adjectives such as 'Indigenous' or 'Indian' or 'Native,' feeling these labels marginalized them within the art world. Today, however, many have proudly taken on the mantle of Indigeneity, in large part because it suggests a particular consciousness shared by other First Peoples in other parts of the world (see McMaster 2017).

\footnotetext{
*Corresponding author: Prof. Dr. Gerald McMaster, Wapatah Centre for Indigenous Visual Knowledge, Ontario College of Art and Design University, Toronto, Canada, e-mail: gmcmaster@faculty.ocadu.ca
} 
Recently, Canadian colleges and universities have begun addressing the idea of decolonizing knowledge. Canada has long seen its European antecedents as the fulcrum upon which our intellectual and cultural foundations are balanced. But this is slowly changing. The Ontario College of Art and Design University (OCAD University) where I work, for example, has adopted as one of its main guiding principles the idea of

decolonization [...] [as part of its] commitment to creating an inclusive and accessible environment that is open, dynamic and representative of an institution known as the 'university of the imagination.' [...] Through a process of ongoing reflexivity, we will more prominently include social justice, critical methodologies, and Indigenous knowledges in our relations, curricula, pedagogy, research practices, policies, and processes. (OCADU 2017, n.pag.)

In this paper, I will discuss the work of several Indigenous contemporary artists who address the question of Indigenous knowledge in their works. The prominent Anishinaabe artist Norval Morrisseau led the way in combining ancient mythos with a contemporary art practice, while the gifted Carl Beam enlarged contemporary practice with ancient building practices. For his part, Beau Dick brought mask-making into a ritual context as a contemporary art practice, and Peter Clair sees abstract formulations in the time-honoured craft of basketry. In his wide-ranging body of work, Edward Poitras brings to life the cultural hero Coyote, Christi Belcourt's studies of medicinal plants inform her paintings, and Bonnie Devine takes familiar forms and creates stories around canoes and baskets. Finally, Adrian Stimson performs the trickster/ruse myth in the guise of a two-spirited character, and Lisa Myers's work with the communal sharing of food typifies a younger generation of artists re-engaging with traditional knowledge.

If making exists within a circle, art and spirit occupy the space directly opposite from one another, the life force of each shifting back and forth: art is spirit; spirit is art; and both are enveloped by and make up part of what we understand as 'Indigenous knowledge.' It would be difficult, if not impossible, to separate art from knowledge in order to specify how one influences the other - and this is true for Indigenous communities across Turtle Island (North America). From the eastern woodlands to the Northwest Coast to the Arctic, the making of art is a vital process, a means of mediating between natural phenomena and the spiritual world, both of which are, additionally, integral to the production of Indigenous knowledge. Of course, contact with Europeans introduced new tools and so-called civilizing rituals designed to make certain ways of living, thinking, and creating obsolete. Those imperial processes forever altered the course of both Indigenous art and knowledge, and yet many First Nations, Métis, and Inuit artists managed (and continue to manage) to imbue their work with materials, practices, and languages derived from their ancestors. At the same time, the artists about whom I 
will speak (and many others, both historical and contemporary) have adapted their work to suit a global art market. Some have even pushed back against the notion that their art must depict Indigenous subject matter by including objects, shapes, or glyphs that reference Indigenous spirituality. These visual artists all have aspects within their work that honour ancient traditions as well as aspects that diverge from it (for example, the adoption of modern media, including video, photography, and performance). They all, in a word, have created bodies of work that speak to their, and our own, current moments in time, Indigenous or not.

Artists of all stripes have moved away from fixed boundaries of art, and contemporary art practices have flourished under globalizing trends that push at these edges. Indigenous contemporary artists are no different in the ways they are addressing questions of identity, gender, sexuality, colonization, and politics. The question of Indigenous knowledge is one that has been slowly surfacing in the wake of decolonial practices that question power relations. Recent Indigenous political efforts, such as the Idle No More movement, or the release of the Truth and Reconciliation Commission Report in 2015, have awakened the Canadian body politic to revolutionize its institutional consciousness. The principle of restitution, in particular, is empowering Indigenous artists to re-examine their practices, and one vital way involves embracing traditional knowledge.

The World Intellectual Property Organization (WIPO) defines traditional knowledge as "a living body of knowledge passed on from generation to generation within a community. It often forms part of a people's cultural and spiritual identity" (WIPO 2018, n.pag.). While the term 'Indigenous knowledge' has its advocates, some detractors, such as the British anthropologist Brian Morris, prefer the term "folk knowledge" (Morris 2010, 1), in that he sees the term "Indigenous" as problematic because it can be applied to anyone, anyplace, who possesses a particular local knowledge. I would agree to the extent that the term has complicated and wider associations, but I am interested in its more localized setting of Canada where 'Indigenous' both defines a relation with others (i.e. colonizers) and serves as a legal term. Furthermore, I would concur with Morris's definition of folk knowledge, which includes local, shared, empirical, practical, informal, and changing as its characteristics (Morris 2010, 2-3). Moreover, the collaborative scholarship of Ray Barnhardt and Angayuqaq Oscar Kawagley illuminate Indigenous traditional education as being

carefully constructed around observing natural processes, adapting modes of survival, obtaining sustenance from the plant and animal world, and using natural materials to make their tools and implements. All of this was made understandable [they argue] through demonstration and observation accompanied by thoughtful stories in which lessons were embedded. (Barnhardt and Kawagley 2005, 10) 
The idea of Indigenous knowledge construed in this way lies at the foundation of many Indigenous contemporary artists' practices. Through the following examples, we may develop a richer understanding of this dimension of their creativity, as well as begin to recognize the audacity of Indigenous peoples and artists to demand a greater voice in the ever-expanding discourse of contemporary art.

\section{Copper Thunderbird}

Self-taught Anishinaabe artist Norval Morrisseau (1931-2007) was a painter of spiritual legends that were passed down to him through his maternal grandparents and tribal elders. Because the Anishinaabe of northwestern Ontario (where Morrisseau was born) preserved their oral heritage, Morrisseau's attempts to capture his culture's myths and stories was met by many in his community with a mixture of disapproval and anger; and yet Morrisseau persevered, determined to visually record the stories he had absorbed as a child as a means of keeping them, and thus the history of his people, alive for future generations. As well-known Canadian broadcaster and cultural critic Lister Sinclair explained back in 1979, "Morrisseau felt a powerful urge to express these stories in visual images. But because of the strong objections of the elders in his tribe, he suppressed his wish to make a permanent record for some time" (Sinclair et al. 1979, 12). Morrisseau's gallery dealer Jack Pollock continued the story:

It suddenly struck [Morrisseau] that he had broken a fundamental Anishinaabe taboo which forbids the pictorial representation of its legends. The elders of his tribe had not endorsed his mission to become the preserver and transmitter of their culture. (Sinclair et al. 1979, 24)

Morrisseau himself concluded in the same volume: "The Anishinaabe people were very unhappy about me sharing secrets to the white people. There is what some people call a taboo, and a taboo is hard to break. But my grandfather said, 'Go ahead'” (Sinclair et al. 1979, 46). By breaking this ancient taboo, Morrisseau prepared the ground for future generations of Indigenous artists who sought to reach into the past to make sense of the present.

Morrisseau's figure looms large over the Canadian art landscape, especially amongst Indigenous contemporary artists. He is perhaps one of the best examples of how Indigenous knowledge and spirituality combine to create art, and how art informs and aids the continuation of Indigenous knowledge - for Indigenous and non-Indigenous people alike. His imagery clearly and forcefully harked back to ancient Anishinaabe myths; he included serpents, bears, beavers, and other Woodland animals; the Anishinaabe story tree; the lake-dwelling creature 
Mishipeshu who lives in Lake Nipigon and takes the form of a half-man, halfserpent (known by Anglophones as mermen); Woodland floral designs; and the Thunderbird god (in English, the Anishinaabe name bestowed upon Morrisseau means Copper Thunderbird). Archaeologist Donald C. Robinson has stated of Morrisseau that, "by recording these myths and legends," his practice "forms a unique legacy that documents the history of his people" (Robinson 1994, 6). But Morrisseau's documentation also opened up new ways of understanding and interpreting his ancestor's myths, enabling younger generations of First Nations artists to tap into the power these stories hold and, in turn, reinterpret them for the twentieth and twenty-first centuries.

For example, Morrisseau's Thunderbird Emblem with Power Signs depicts the Thunderbird with wings outstretched, "enclosing and protecting the spirits of the people" (Robinson 1994, 7). Morrisseau visualized the Thunderbird legend by transforming the oral stories he heard as a child. In his art, this powerful god thereby became a physical being capable of defending his people against the forces of evil - in whatever form they might come. Spiritual or physical, past or present, the pain one feels moving through the world is healed through this vision of the Thunderbird. Indeed, all of Morrisseau's paintings are created to remind the viewer, in Morrisseau's own words, that "you're an Indian. We are all Indians. It's not your fault that you were born with a certain skin colour. Somewhere inside, we're all Indians. I'm trying to bring out the best Indian-ness in you to make you realize everything is sacred in this world" (qtd. in Robinson 1994, 7). Norval Morrisseau was not just a painter; he was a shaman-artist, able to articulate through brush and paint themes that continue to be vital for Indigenous people and artists: resilience, the importance of childlike curiosity, the joy of colour, and the interconnectedness of all living things.

\section{Carl Beam}

Unlike Morrisseau, Carl Beam (1943-2005) preferred to be understood by the public, art dealers, and curators as a pluralistic artist, concerned not only with the (re-)production of his Anishinaabe heritage but also with contemporary issues that affected him as a person with a specific history and lived experience. This does not necessarily mean that Beam disregarded his Indigenous heritage, but rather that he provided, through his work, a direct challenge to preconceived notions about Indigenous art, spirituality, and knowledge. In fact, curator Joan Murray contends that when Beam began working as an artist in the 1970s, he “found Morrisseau's style lacking in relevance as contemporary art” (Murray 
2002, ix). Murray continues: "like many artists of the 70s who were reacting against abstraction, he turned to photography-based imagery as the medium most suited to his themes of identity" (Murray 2002, ix). Photography enabled Beam to express his pluralistic identity most easily, in part because photographic materials are easily collaged with other media to allow for the existence of several different aesthetic or emotional positions within a single artwork.

Beam's use of material and collage specifically enabled him to wrench past events or moments into the present, demonstrating how the past had shaped him (the son of an Anishinaabe mother and a European father), and how the present mingles, reacts, and pushes back against such events. Beam mixed images of Einstein, Sitting Bull, the Hubble Telescope, X-Ray scans, and pages from newspapers. In Eric and Jennifer from 2002, for example, Beam combined photographs of whaling and Jennifer Lopez, and a clipping from Rock \& Roll magazine waxing poetic about “Eric Clapton's Golden Age.” Taking stock of this approach, Murray argues that Beam "wanted to suggest that we learn to dissolve conceptions of reality based on traditions that have marred our sense of identity. He had come to understand, and wanted to convey [through his art], that culture is a flexible system of interrelations" (Murray 2002, 6-7). But Beam himself also wanted his work to speak to self-awareness and personal responsibility, and he found in collage a particularly effective way to convey both survival and subjectivity. Here he is in his own words:

If you have your own face next to a rocket, if you have your own face next to the Sadat assassination, this, to me, implies that one [...] has to have personal responsibility for world events. You have to respond personally. Everybody eventually has to learn how to respond or to filter what's happening through their own senses. (qtd in Grande 2014, 181)

Beam's desire to engage the senses and find fresh ways of understanding the world around him extended from the creation of two-dimensional works to threedimensional ones. In 1992, he began experimenting with building adobe houses at the Arnold Gottlieb Gallery in Toronto. What began as a smallish project consisting of a few hand-made moulds of adobe bricks and architectural blueprints set on a table in the gallery transformed, a few months later, into a large-scale, custom-built home in West Bay, Manitoulin Island (Grande 2014, 186). John Grande considers Beam's Adobe Project a critique of the housing crisis, an examination of "the relationship of housing debt to poverty," and a questioning of "the concept of the modern single-family dwelling and the purported aspirations it represents for suburban middle-class life in Western culture” (Grande 2014, 186). More than that, however, Beam's adobe houses are a physical manifestation of his desire to blend the past with the present, to see, as Grande states, "culture as a flexible 
system of eco-dependent interrelations [...] vital to the survival of mainstream Canadian culture [and] Canada's first inhabitants" (Grande 2014, 188). Beam had spent the late 1970s and early 1980s in New Mexico, where he learned about the properties of adobe from local Pueblo Indians. For a long while, he created small works reminiscent of pottery. But it was not until he moved back to Manitoulin Island - an enormous freshwater island in Northern Ontario where the majority population is First Nations - that he began to apply the Indigenous knowledge of the American Southwest to his local community. Despite some negative reactions, he persevered. Although Beam died many years ago, his wife continues to live in the adobe house at West Bay. And although his ideas never caught on locally, the art community still regards him as an important visionary.

\section{Beau Dick}

Kwakwaka’’wakw artist Beau Dick (1955-2017) held an important position in Canadian art history. Hailing from Alert Bay on the northeast coast of Vancouver Island, Dick started his woodcarving practice at the age of fifteen under the guidance of his grandfather, Jimmy Dick, and his father, Ben Dick. In his early twenties, Dick innovated within the visual vocabulary of his people's traditional iconography by infusing contemporary elements into his works. Many of his carvings are depictions of characters from Kwakwaka'wakw culture, while some appear to be more contemporary in shape and use experimental colours. "He had a special knack for art,” says Chief Joseph, who watched him grow up:

He would sit by his father and grandfather and other carvers and watch them whittle all day and he soon began to whittle and became the artist that he was. He developed his artistry [Joseph recalls] from some pretty prominent [...] Kwakwaka’wakw artists like Douglas Cranmer and Tony Hunt as well as Haida artists like Bill Reid and Robert Davidson. (qtd in Lederman 2017, n.pag.)

Dick's craftsmanship lineage afforded him the sensibility required to bring coastal traditional carving closer to contemporary art. Dick often reached out to parallel world carving traditions, such as from Europe and Asia, and engaged them in fertile dialogue. Reaching out beyond the confines of his own Kwakwaka'wakw culture, Beau Dick not only mastered the styles of other tribal traditions, while still remaining respectful of each, but he said taking his work into the marketplace afforded him monetary access to continue doing traditional work. He has also stepped into the realm of contemporary art in paintings that draw on European precedents but express the powerful mythology of his own culture. 
Today, Dick is likely most well-known and highly regarded for his carved masks, which embody powerful ceremonial elements. He described his style as

Potlatch style [as] it comes from a tradition of ceremony which requires many masks to be made in a short period of time. It takes many years of practice and an understanding of balance in order to create a work that appears finished in a natural and instinctive manner, without seeming overthought. (Fazakas Gallery n.d., n.pag.)

The retention of prominent Northwest Coast iconography is present throughout his forty-year career of mask-carving, a consistent and strong palette of black and red lines creating ovoid and U-forms on the masks. Dick often employed natural material - plants, animal hair, and feathers as hair - for his masks, signifying strong ties to the land. In cases where he attempted to tackle non-Indigenous subjects, the formal elements of Northwest Coast art are still identifiable in the carved shapes of facial features, such as open mouths, bird-like noses, and round eyes. Dick worked intuitively to bring these elements to life. He did not preplan how he wanted a mask to look; he interacted with each wood block in a ceremonial manner, asking what it wanted to be. Dick's entire process of artmaking played out like a performance in which the sense of inevitability and rightness guided the visualization of the mask (Thom 2009, 36).

Having learned from master carver Douglas Cranmer, Dick never told the same story twice; indeed, he believed that any given story "is not always the same” (Thom 2009, 36). Regardless of formal resemblances among his masks, every time a new one was created and interpreted, a story was born anew. Although they are contemporary, Dick's masks reflect the ceremonial spirits and traditional purpose of Kwakwaka 'wakw carved masks. They represent archetypes standing in for the tribal teachings, stories, and virtues Dick learned from his father and grandfather.

\section{Peter Clair}

One fascinating individual using traditional practices to make art in the present day is Mi'kmaq basket weaver artist Peter Clair. For Clair, art-making happens at the intersection of artist and concept. In his words:

The affair begins with the artist catching glimpses of exciting, disturbing or sensuous images that originate from the finite physical world or the infinite mental world. They respond to each other, and when their emotions heave and explode they discover that they have to share an eye to see the result of their union in the form of art. (Clark 1997, n.pag.) 
Having learned to weave from master weavers and artists, such as Agnes Clair, Shirley Bear, and Sylvester Augustine, Clair combines traditional weaving techniques to create contemporary basketry sculptures. As a result of this melding, his works often appear original, and sometimes humorous. The weaving process itself is time and labour consuming. Additionally, to make a successful basket, a weaver must have a comprehensive knowledge of "creation stories, crest designs, spirituality, respect, knowledge, power, virtue, and the deep understanding of the land" (Spahan 2010, 12).

Clair's baskets, as seen in the international exhibition of Indigenous weavers, $S M A S H$, in 2010 at the Art Gallery of Greater Victoria in British Columbia, stay close to forms of Mi'kmaq baskets, while the material and decorative elements make them more contemporary. Mi'kmaq baskets are often made of ash, maple, and poplar wood splints, whereas decorative elements are made with sweetgrass. Bottom warps and wefts are woven in round, square, or rectangular shapes. The weaver then bends the unwoven ends vertically to form warps for the sides, which are woven to the desired height. Towards the end of the process, the outside warps holding the last row of weaving in place are turned down to create a rim around the basket.

Pre-contact Mi'kmaq baskets were undecorated. This changed, however, when they entered European traders' supply-and-demand stream. As demand for Indigenous art and craft surged during the heavy trade periods of the nineteenth century, Mi'kmaq weavers responded "by dying the wood splints in bright acrylic colours, adding aromatic sweetgrass and embellishments such as curls and folds, [and] the baskets became very appealing as decorative items in Victorian household[s]" (van der Hooft 2015, 132). Mi'kmaq weavers developed a new category of "fancy baskets” with diverse motifs and patterns (Gordon 2011, n.pag.). Today, Mi'kmaq art - including baskets - is influenced by many directions and philosophies, and artists and craftspeople use any and all available materials to re-indigenize.

In addition to their elaborate decoration, the production of fancy Mi'kmaq baskets was facilitated by the introduction of two new tools: "wood blocks around which the baskets were shaped, and gauges which cut the wood into more narrow splints that were easier to use for elaborate decorations" (van der Hooft 2015, 132). Traditionally, weavers would split wood into splints using a knife and weave their baskets freehand. The adaptability of Mi'kmaq artists to new technology is one of many virtues that Clair still continues to practice in his own craft. Clair has also embraced the computer as an integral tool in making and understanding contemporary Mi'kmaq basketry. As he noted in his SMASH exhibition artist statement:

In an attempt to re-indigenize Aboriginal art, there is a hegemonic influence. Ag pulwelk Migmewei ntepwigesigel gisagajatumkl ujit gesgmasimkewie - and there is much Mi'kmaq art that has been digitized for computer. (Clair 2010, 80) 


\section{Edward Poitras}

Métis artist Edward Poitras explores themes of Indigenous history through his sculptures and installations. His art tells stories of treaties, colonialism, and the experience of living on reserves and in cities. Throughout his career, Poitras has used coyote iconography as the main subject in his storytelling. His coyotes are often depicted during processes of transformation from "bones and other materials” into animated living creatures (LaVallee 2011, n.pag.). Poitras’s sensorial sculptures take viewers to imaginative territories that are beyond identity and location. He situates his coyotes on a global level, bringing together shared histories and entangled narratives in the interpretation of his works.

In his 2012 solo exhibition entitled 13 Coyotes at the MacKenzie Art Gallery in Saskatchewan, Poitras exhibited alongside his bone-coyote sculptures reference documents containing information related both to history as well as his own artistic process. By doing this, Poitras showed the sources of his creations while also tracing a globally entangled web of narratives. As a young art student at the Saskatchewan Indian Federated College in Saskatoon, where he studied under the renowned Indigenous artist, poet, and educator Sarain Stump, Poitras was frustrated at the lack of stories of systematic destruction being taught in schools (Tousley 1995, 43). He wanted to create art that did not perpetuate "traditional cultural objects whose functions were lost when they became collector's items" (Tousley 1995, 43). Moving away from the 'Indian' formals, Poitras started making works that could have a global formal language while focusing on stories, histories, and narratives that were being shared and exchanged among global Indigenous communities. Poitras encouraged challenges against 'documented' histories, seeking to give agency and validity to narratives that had been brushed aside.

Poitras's approach, in combination with his use of the coyote icon, involves intuitive thought and an in-depth understanding of Indigenous cultures, as well as of "their relationship to ritual, art, and the environment" (Everett 2008b, 159). He chooses bones as the medium for his sculpture because they are a direct reference to his hometown of Regina, Saskatchewan. Prior to being named Regina, the place was called Pile of Bones (Oskana kâa-asastêki in the Plains Cree language). In addition to paying tribute to the city's original name, Poitras's choice of bones as medium for the sculptures symbolizes Indigenous relations to the land, in which the visibility of bones on the prairie landscape marks, as well, the presence of Indigenous people on the land. As Tousley explains:

Bones left after the buffalo hunts littered the prairie; settlers, erasing history, shipped them east to be made into fertilizer. It could be said that Poitras inhabits a complex reality somewhere between Regina and Pile of Bones, a place where he is as agile and elusive as a coyote. (Tousley 1995, 37) 
Coyote as a Trickster appears in many Indigenous stories across Turtle Island. For artists, this nimble figure enables them to go in disguise and travel across cultures that share the same concept. Embodying the role of the Trickster, Poitras embraces contradiction, acknowledging the multivocality of histories and concepts. Poitras's attention to this particular archetype in terms of its ontological and epistemological fluidity stems from his personal history as a Métis - a person who carries both Indigenous and European roots. Poitras sees himself as belonging to a third culture (Tousley 1995, 38). His works become more potent and relevant in our contemporary, post-global context where more and more people are of mixed heritages.

\section{Christi Belcourt}

Christi Belcourt refuses to define her art: "I will leave that to others," she states (Belcourt n.d., n.pag.). Belcourt prefers, instead, to illuminate the forces behind her creation: "Everything that drives me, and drives my art and the mishmash of everything I do in my life is my love for the earth and my awe of it all” (Belcourt n.d., n.pag.). Best known for her 'beaded' paintings, in which she uses acrylic paint on canvas to painstakingly replicate Métis flora and fauna patterns, which were more typically beaded onto moccasins, pouches, and other apparel, Belcourt endeavours to represent spiritual interconnectedness through her art. In her view, "[n]othing is separate from anything else. The spirit world surrounds us at all moments and is present in all things” (Belcourt n.d., n.pag.). For Belcourt, knowledge is inseparable from the land, and the land is what informs her art practice.

Belcourt's paintings and video works speak to this concept on multiple levels. Not only does the artist connect with her ancestors' artistic traditions through her paintings, she also connects to the land on which she lives. The plants she depicts in her paintings exist across North America; most are medicinal and have been used by her Métis ancestors to promote healing. Some of these plants are Indigenous to the continent, while others were introduced by Europeans during colonization. Her painting Medicines to Help Us (2014) provides an example of the ways in which the artist weaves invasive and non-invasive plants together to create a metaphor for Métis resilience, offering her own version of healing through art in the process. Here is what Belcourt has to say about this work:

The roots show that all life needs nurturing from the earth to survive. [...] There are lines that connect the plants to symbolize our interconnectedness with each other and all living things within creation. The flowers and leaves reach upwards as we seek out our individual spirituality and look to our uncertain future. (qtd in David 2004, n.pag.) 
Belcourt's mixing of media and vegetation reveals her deft ability to both critique and appropriate the dominant culture while staying true to her Métis worldview. The 'beads' she paints are not modeled on the shape or colour of the traditional shell beads her ancestors would have used to create patterns on bags or Wampum belts, as this type of bead was typically square or rectangular; rather, the artist's painted dots are closer in kind to Victorian-era glass beads, imported to the region during the nineteenth century by European traders. This aesthetic strategy acknowledges the impact colonialism has had on Métis communities across Canada while also speaking to such communities' resilience, particularly their ability to adapt and thrive in the face of overt oppression. As much as the Canadian state attempted through brutal assimilation policies (including residential schools and the creation of the reserve system and subsequent 'blood quotas') to eradicate Belcourt and her people, past and present, she and her kin have survived. By using and subverting the tools of the oppressor - tools that come in many forms, from paint to flowers to weeds - to practise her art, Belcourt attempts in spreading Indigenous knowledge and healing to a wider audience.

\section{Bonnie Devine}

The next individual I would like to profile is Bonnie Devine, an Anishinaabe installation and performance artist whose practice focuses on telling the stories of her communities. Growing up in the Serpent River First Nation in Northern Ontario, Devine witnessed her community's battles with the inroads of “progress” (Everett 2008a, 34). In her art, Devine combines traditional forms with new materials to address contemporary issues that have effects on Indigenous communities. The merging of traditional sensitivity and new technical approaches can be seen in her 2003 work Canoe. If you have ever visited Northern Ontario, you will know that multiple rivers - great and small - flow through Anishinaabe territory, peacefully carrying sustenance and goods to feed the community. Through her life-size canoe made out of paper, Devine embodied the original Anishinaabe people's ancient relationship to their water-fed land and its flowing waters (Everett 2008a, 36).

With the advent of modernity, however, many traditional Anishinaabe ways of living stopped. The fragility of the paper used to craft the canoe stands in sharp contrast with the sturdiness of cedar and birchbark, materials typically used to create Anishinaabe canoes. Here, Devine visually communicates the stories of mining that have plagued her community and home territory. Not only have those operations disrupted ways of life on the Serpent River reserve, they also carry 
with them ecological consequences that will have damaging impact on her community for generations to come. These concerns are expressed through Devine's excerpts from her thesis written on the body of the canoe containing

descriptions of the birch tree and the traditional technology of building a canoe, the text of the Robinson Huron Treaty of 1850, the document detailing the relationship between the North Shore Anishinaabe people and the government of Canada, and Devine's research into atomic science, the uranium ore that was discovered at Elliot Lake and the effects of its subsequent removal. (Pugen 2004, n.pag.)

Devine sewed and suspended the canoe with beads, twine, and thread following instructions for constructing a rice-gathering canoe she received from Anishinaabe navigators (Devine 2004, n.pag.). The canoe's suspension within the gallery space symbolizes the traumatic experience of displacement created by and through the reserve system. At the same time, the canoe's suspension disrupts such space's penchant for modernism, the canoe serving as a vehicle or container for carrying traditional or historical Anishinaabe knowledge. Devine's paper canoe covered in her research notes is thus a sign of resilience. As Diane Pugen observes:

For Devine's ancestors, the Serpent River [Anishinaabe], the canoe was also a vehicle for survival. It was used to gather the wild rice, a staple food that grows on the water, to transport goods and supplies and to provide for the defence of their territory against predators and invaders, uses which predate European contact. The canoe and Devine's Canoe assert Indigenous sovereignty over these lands and waters. (Pugen 2004, n.pag.)

In order to achieve this sophisticated level of storytelling, Devine builds a strong foundation in Anishinaabe culture from stories told by elders (Everett 2008a, n.pag.). She uses her art to reflect on these stories with her lived experience to find the gap between narrative and experience. In exploring and revisiting elders' stories through art, Devine uses familiar material from her surroundings to rearticulate those narratives in contemporary language.

In her artist's statement, Devine says: "I am interested in the oppositions inherent in the terms of history and memory, science and mythology, art and artifact, and these oppositions and their cultural antecedents form the basis of much of my work" (Devine 2004, n.pag.). Her 1995 basket sculpture Pomo Basket evinces such an interest. This 5-foot-wide sculpture is woven together with coaxial cable, giving it "a functional, highly modern look and a sense of unseen, pulsing energy” (Everett 2008a, 35). The use of contemporary materials enables Devine to create a type of central Indigenous nervous system, weaving together cables as a means to connect distant family and community members, now scattered across Turtle Island. Devine's works are contemporary for a number of reasons: 
the materials used to create them are modern and thus diverge from the materials her ancestors would have used, and her work references current issues and concerns. However, Devine subverts the materials of the colonizer to tell Indigenous stories, a juxtaposition that creates entry points for non-Indigenous viewers familiar with the materials but, perhaps, unfamiliar with the history of colonization and the impacts neoliberalism and global capitalism are having on Devine and her community.

\section{Adrian Stimson}

Looking westward, Adrian Stimson is a member of the Siksika (Blackfoot) Nation. An interdisciplinary artist, his paintings, installations, and videos referencing the buffalo are numerous; he often portrays the character Buffalo Boy, a parody of Wild West icon Buffalo Bill, in his performances. Curators Ryan Rice and Carla Taunton describe Buffalo Boy as a trickster character, one that, I would argue, has certain affinities with Poitras's Coyote I discussed earlier. "Part drag performer, part shapeshifter,” Rice and Taunton observe,

Stimson's Buffalo Boy relies on his prairie-nurtured chameleon intuition - an amalgamation of Rez smarts and street smarts with traditional Indigenous knowledge and contemporary queer theory - to camp up colonialism, sexuality and authenticity. (Rice and Taunton 2009, n.pag.)

Like all the artists I have discussed so far, Stimson's creation of Buffalo Boy represents an act of "survivance." Rice and Taunton describe Indigenous survivance as an idea that "links Indigenous survival, resistance and continuance to the presence of stories and the continued acts of re-telling” (Rice and Taunton 2009, n.pag.). Stimson's (re)embodiment of the buffalo (long eradicated from the wild by settlers) in the character of Buffalo Boy refutes colonial interpretations of Indigenous ways of life - particularly historical artworks and anthropological writings that describe Indigenous peoples and their culture as dying or, worse, already dead. A "neo-trickster," Buffalo Boy uses play and humour to subvert European ideas of Indigeneity, calling upon common stereotypes in order to "reclaim and revision Indigenous identities" (Rice and Taunton 2009, n.pag.). In this way, Indigenous knowledge is carried into the present through performance.

Where performance and dance historically existed within Indigenous cultures as a means to connect with the spirit world, Buffalo Boy makes them a means by and through which Indigenous people can connect with current processes of colonization. These processes include isolation via the reserve system, 
the enforcement of European gender norms (Buffalo Boy identifies as two-spirit), and the destruction of land and animals - notably, the buffalo, which Stimson has said he uses as "a symbol that represents the destruction of the Aboriginal way of life, but it also represents survival and cultural regeneration. [...] The whole history of its disappearance is very much a part of my contemporary life" (qtd. in Rice and Taunton 2009, n.pag.).

\section{Lisa Myers}

The final person I wish to discuss is Lisa Myers, another Anishinaabe interdisciplinary artist and curator whose practices focus on the politics of food and land. Myers brings to art her personal experience as a cook as well as of growing up in the Georgian Bay and Lake Ontario regions. Considering walking and cooking as research methods for art making, Myers in her art uses "a range of media and materials including printmaking, sewn structures, film, video projections, audio and the assemblage of materials such as food, seeds, canvas, and beads" (Aboriginal Curatorial Collective 2016, n.pag.). Applying a similar creative process to cooking, Myers explores the stories, origins, and cultivation of each ingredient to a meal. The experience with her art is often boundless in community food projects and insightful in visual projects. In both endeavours, Myers focuses strongly on the roles of food and place in her artistic experience.

Her most well-known project, Each Portion, first premiered at the Art Gallery of Ontario during Nuit Blanche in Toronto in 2015. Each Portion is a stop-motion animation of a series of wooden spoons pigmented with blueberry, seeking to engage viewers' associations and memories triggered by food. Starting from berry-picking from various sites around Ontario, the project invited people into the Community Gallery through the early part of September 2015 to contribute to the animation by experimenting with the absorption of blueberry pigment on wooden spoons. The spoons were photographed for the creation of the video and then displayed in the Community Gallery alongside other work by Myers in the exhibition (Mierins 2015, n.pag.).

This project was an extension of Myers's 2008 work entitled Strawberry Spoons. For that one, Myers picked the strawberries and then made drinks out of them. Afterwards, she used wooden spoons to experiment with the dip line to create a mark that continues along each spoon. When they are juxtaposed, Strawberry Spoons and Each Portion evoke Myers's deep understanding and affection for the land and its resources. Native to North America, blueberries and strawberries carry in them stories of ancestors and traditions. The act of cooking or juicing 
these fruits evokes a ceremonial experience through which Myers reconnects to traditional knowledge through the communal preparation and sharing of food.

In a more visual work, Crossing Tracks (2015), Myers used anthocyanin pigment from blueberries as ink. The complexity of human nature is captured in this piece and articulated with minimal imagery. The tracks seen here go beyond visual interpretation to engage with representations of land. They appear as marks that are drawn from the sustenance certain places can provide. Consequently, they guide one's perception of a place towards a sense of belonging, of knowing where these tracks come from and go to. As the tracks cross each other on a blank background, they create a point of contention, diverting a viewer's attention to another track, or interrupting one's train of thought. Indeed, when viewed from afar, the tracks also resemble rivers - perhaps a link between her work and that of fellow Anishinaabe artist Bonnie Devine.

However we interpret them, these multivalent 'tracks' speak to Myers's ability to maintain Indigenous sensitivity and subjectivity without the need to use common Indigenous iconography. As an Indigenous person of anew, Myers's method-based practice challenges stereotypical Indigenous art imagery in the conventional art scene. Her Indigeneity comes through her conscious and ceremonial process of engaging with material collected from the natural environment. The unpredictability and minimalist aesthetics of her visual outcomes exceed the visual boxes that define Indigenous art in North America. By going back to the basic acts of cooking and walking, Myers is able to connect her art with any Indigenous person in any country, while still promoting a Canadian Indigenous sensitivity.

\section{Conclusion}

I hope that my readings of works by artists Norval Morrisseau, Carl Beam, Beau Dick, Peter Clair, Edward Poitras, Christi Belcourt, Bonnie Devine, Adrian Stimson, and Lisa Myers have given the reader a refreshing insight into Indigenous contemporary art in Canada. All of them apply contemporary materials, combining them with practices and methodology they have learned from their communities through stories, ceremonies, performances, and personal experiences. Their innovations with materials, technologies, and display modes have gained them recognition among non-Indigenous colleagues, artists, and critics worldwide. Last, their ability to represent various types of traditional knowledge without resorting to stereotypical Indigenous imagery opens new ways to learn about and interpret the art of Indigenous people, not only in Canada but in other 
places as well. Their curiosity, will to experiment, and rejection of clichés liberate Indigenous artists from the pigeonhole set by nineteenth-century European consumers.

\section{Works Cited}

Aboriginal Curatorial Collective (2016). “Lisa Myers.” Kwần Mày Dáyè Dàátth'i - Sit by the Fire with Us * Ensemble autour du feu. <https://www.kwanmaydayedaatthi.com/lisa-myers/ > (December 18, 2017).

Barnhardt, Ray and Oscar Kawagley (2005). “Indigenous Knowledge Systems and Alaska Native Ways of Knowing." Anthropology and Education Quarterly 36.1, 8-23.

Belcourt, Christi. Artist's Webpage. <www.christibelcourt.com > (December 18, 2017).

Clair, Peter J. (2010). “Peter J. Clair.” Smash: International Indigenous Weaving. Victoria, BC: Art Gallery of Greater Victoria, 80.

Clark, Janet E. (1997). Epogan: Recent Work by PeterJ. Clair. Thunder Bay, ON: Thunder Bay Art Gallery.

David, Jolene (2004). "Métis Artist Launches Her First Solo Exhibition.” Ontario Birchbark 3.1. <https://search-proquest com.ocadu.idm.oclc.org/docview/196624262/abstract/5A95719 EF1164DA7PQ/1?accountid =12991> (December 10, 2017).

Devine, Bonnie (2004). "Stories from the Shield." Stories from the Shield: Bonnie Devine. Brantford, ON: Woodland Cultural Centre. <http://ccca.concordia.ca/c/writing/d/devine/ dev002t.html > (June 23, 2018).

Everett, Deborah (2008a). “Bonnie Devine.” Deborah Everett and Elayne Zorn, eds. Encyclopedia of Native American Artists. Westport, CT: Greenwood Press, 31-34.

Everett, Deborah (2008b). “Edward Poitras.” Deborah Everett and Elayne Zorn, eds. Encyclopedia of Native American Artists. Westport, CT: Greenwood Press, 158-160.

Fazakas Gallery (n.d.). "Beau Dick - Fazakas Gallery." <http://fazakasgallery.com/artists/ beau-dick/\#1474558360939-147d58dd-c818> (December 18, 2017).

Gordon, Jorleen (2011). “Mi'kmaq Basketry.” Ornamentum. <https://ornamentum.ca/mikmaqbasketry/> (December 18, 2017).

Grande, John K. (2014). “Carl Beam: Dissolving Time.” Balance: Art and Nature. Ottawa, ON: Black Rose Books, 178-188.

LaVallee, Michelle (2011). “13 Coyotes: Edward Poitras." Curatorial Statement. Regina, SK: MacKenzie Art Gallery. <http://mackenzieartgallery.ca/engage/exhibitions/this-isexhibition-number-four $>$ (December 18, 2017).

Lederman, Marsha (2017). "Beau Dick, Master Carver, Created Haunting Indigenous Works." Globe and Mail.<https://www.theglobeandmail.com/arts/beau-dick-master-carvercreated-haunting-Indigenous-works/article34714196/> (December 18, 2017).

McMaster, Gerald (2017). “Under Indigenous Eyes.” Art in America 105.9, 64-71.

Mierins, Krystina (2015). "Food for Thought.” Magenta Magazine. <http://www.magentafoundation.org/magazine/food-for-thought/ > (December 18, 2017).

Morris, Brian (2010). “Indigenous Knowledge.” The Society of Malawi Journal 63.1, 1-9.

Murray, Joan (2002). Carl Beam: The Whale of Our Being. Oshawa, ON: The Robert McLaughlin Gallery. Exhibition catalogue. 
Ontario College of Art and Design University (2017). Academic Plan 2017-2022. Toronto, ON: OCAD University.

Pugen, Diane (2004). “Stories from the Shield: Bonnie Devine.” Bonnie Devine, Tom Hill, Robert Houle, and Diane Pugen, eds. Stories from the Shield: Bonnie Devine. Brantford, ON: Woodland Cultural Centre. <http://ccca.concordia.ca/c/writing/d/devine/dev002t.html. > (December 15, 2017).

Rice, Ryan and Taunton, Carla (2009). "Buffalo Boy: THEN AND NOW.” INDIANacts. <http:// indianacts.gruntarchives.org/essay-buffalo-boy-then-and-now-rice-and-taunton.html> (December 15, 2017).

Robinson, Donald C. (1994). “Introduction.” Norval Morrisseau: Honouring First Nations, May 7-31, 1994. Toronto, ON: Kinsman Robinson Galleries, 4-8.

Sinclair, Lister, Jack Pollock, and Norval Morrisseau (1979). The Art of Norval Morrisseau. Toronto, ON: Methuen.

Spahan, Rose M. (2010). “Curator’s Introduction.” Smash: International Indigenous Weaving. Victoria, BC: Art Gallery of Greater Victoria, 11-14.

Thom, Ian M. (2009). "Beau Dick." Challenging Traditions: Contemporary First Nations Art of the Northwest Coast. Vancouver, BC: Douglas \& McIntyre, 33-36.

Tousley, Nancy (1995). "Métis Artist Edward Poitras in His New Installation for the Venice Biennale Turns the Tables on History." Canadian Art, 36-45.

van der Hooft, Meete (2015). "Woodsplint Basket." Pieter Hovens and Bruce Bernstein, eds. North American Indian Art: Masterpieces and Museum Collections in the Netherlands. Altenstadt: ZKF Publishers, 132.

World Intellectual Property Organization (2018). “Traditional Knowledge." $<$ http://www.wipo. int/tk/en/ > (June 23, 2018). 